シンポジウム $\mathrm{I}-5$

\title{
Leukocyte dialysate (transfer factor)
}

一その生物学的活性と臨床的応用一

\begin{abstract}
斎藤 晃治
Key words : leukocyte dialysate, transfer factor, pustulosis palmaris et plantaris, subacute sclerosing panencephalitis, chronic hepatitis $B$
\end{abstract}

\section{はじめに}

Transfer factor (TF) は Lawrence ${ }^{1)} に よ り$ 発見さ れた白血球由来の可透析性物啠で delayed type hypersensitivity（DTH）を伝達することで知られる因子であ る. 現在, TFとして臨床応用に用いられているものは, 実は白血球抽出物加ら透析により得られた leukocyte dialysate (LD) であり，そこには TF のほか，血球由 来の多数の低分子物缺が混在する゙2. したがって，LDを 臨床的に投与寸る場合、これらの物質はそれそれの生物 活性を発揮し，その総和としての臨床的効果が発現する ことになる，そこでまず，LD 中に存在する生物活性物 梊についての知見を整理し，LD の臨床応用とその有効 性について述べたいと思う。

\section{Leukocy te dialysate (LD) 中の生物活性物質 \\ 1) LD の作暼}

現在，本邦で臨床的に用いられているLDの多くは， TF という名称で日本赤十字血液センターを中心として 作製されている，すなわち，上卜末梢血から白血球を分 離し, Lawrence 法"1従って凍結・融解 6 回繰り返 L, DNase $\cdot \mathrm{MgSO}_{4}$ を添加後, $37^{\circ} \mathrm{C}, 30$ 分間 incubate する。ついで，48 時間透析を行ない，透析外液を凍結乾 燥させ, $280 \mathrm{~nm}$ における吸光度が 50 に相当する量を 1 単位として調整されてある。

我ヶ ${ }^{3,4)}$ の教室では透析の工程を分子量 10,000 dalton のフィルターで限外沪過を行なった ultrafiltrated leu-

和歌山県立医科大学第 2 病理 kocyte extract (ULE) を基碳的研究に用いている.

\section{2) LD 中の生物活性}

現在までに報告されている LD 中の重要な生物活性を 表1に示したが、これらのほとんどのものは純化・同定 されていない.これらのうち，臨床的に特に重要なもの について述へてみよう。

(1) Transfer factor (TF) 活性

TF は donor が感受性を有する DTH のみを感受性 のない recipientに 特異的に伝達する白血球由来の因子 であり, donor の DTHが強ければ強いほど、その伝達 活性も強いと言われている.その生化学的性質は不明で あるが, 抗原を含まず, 免疫原性・組織適合抗原を有さ

表 1 LD 中の生物活性

A. 抗原依存性活性

1. donor 特異性 DTH 伝達活性（transfer factor $)^{1,5-6)}$

2. adjuvant 活性 (augmentor) 2 3,7 8)

3. DTH反応抑制活性 (suppressor) ( $^{7-12)}$

4. 抗原添加による感作りン八球增殖促進活 性 ${ }^{13)}$

B. 抗原非依存性活性

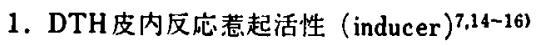
2. Eロゼット形成能回復促進活性 ${ }^{17}$
3. リン八球DNA合成促進·抑制活性 ${ }^{11-12,18)}$
4. 走化性活性 $\left.{ }^{4}, 19\right)$
5. 白血球遊走抑制活性 20 21)
6. インターフェロン誘起活性 221
7. 単球内 cGMP 刺激活性 23 )
8. $\mathrm{T} \gamma$ 内 CAMP 刺激活性 ${ }^{24)}$ 


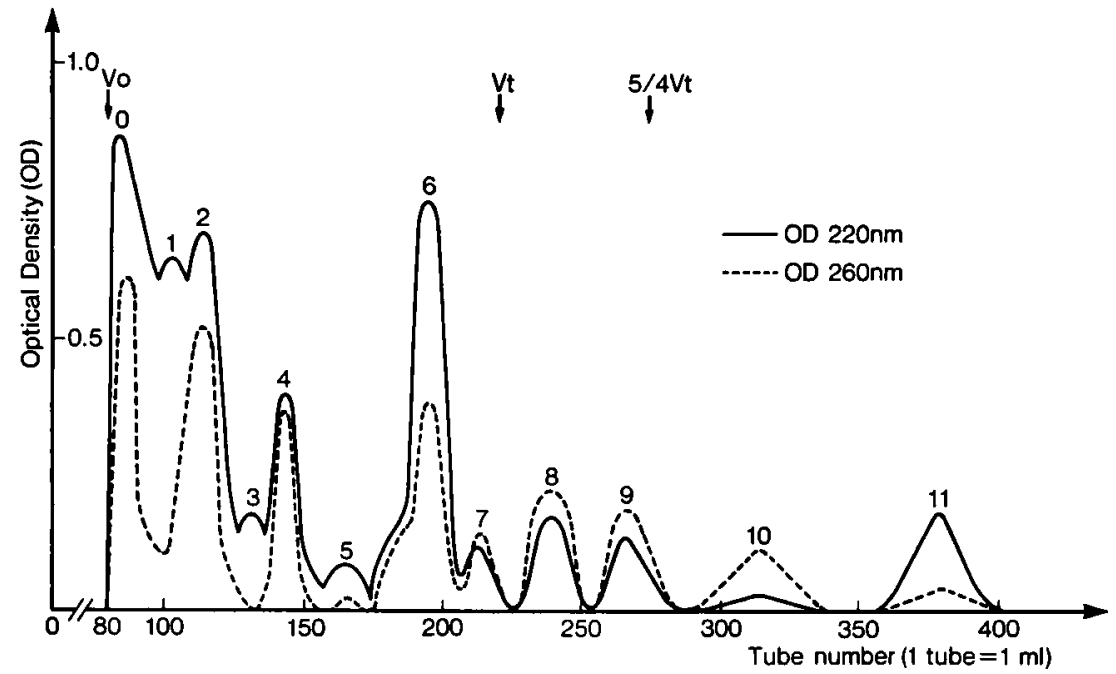

図 1 Sephadex G-10 カラムクロマトグラフィー

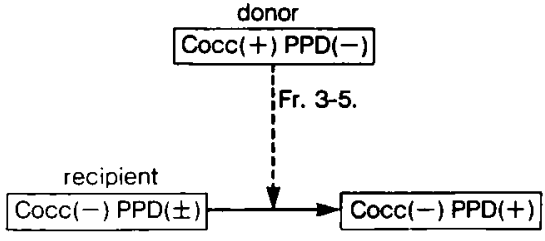

a.

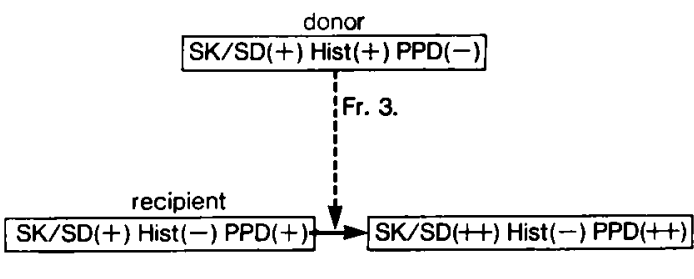

b.

图 2 皮内テスト

ない低分子物質とされるが，その詳細は Lawrence の 総説 ${ }^{5,6)}$ を参照されたい，以前から，この伝達活性を期待 して臨床応用がなされ，カンディダ抗原に感受性を有す る donor から作製した LD 慢性皮膚カンディダ症患 者に投与し，臨床的に有効であったという多くの報告が なされている ${ }^{25,26)}$ また，同様に慢性真菌症 ${ }^{27)}$ ・ウイル

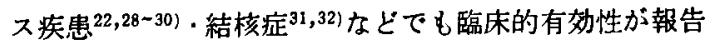
されている。

\section{(2) Adjuvant 活性}

TF に関する最大の問題点は特異的伝達活性の有無に あり，TF の存在に疑問をもつ研究者も多い7 8,33-35). すなわち，LD 投与後に DTH 皮内反応の陽転化が認め られたとしても，donor の DTHが recipientに伀達さ れたのか，あるいは皮内反応では確認しえなかった弱い recipient $の$ DTH が非特異的に增強されたのかは不明 である.この後者, すなわち, LD 中の adjuvant 活性 を有する物質を著者らは TF と区別する意味で augmentor ${ }^{2 \sim 3), 7-8)}$ と名うけけ検索してきたが，ここでは， これが TFとは異なる物質であるという根拠を皮内テス トを中心に少し述べてみる。

\section{(a) Augmentor の分噰}

前述のように, 末梢白血球から得られた ULE を分画 分子量 5,000 dalton のフィルターで再度限外沪過を行 ない, 分子量 5,000 以下の分画を得る.これをさらに Sephadex G-10 カラムにより分画し, 各画分の optical density $220,260 \mathrm{~nm}$ で测定すると, 図 1 のうに, 12 個のピークに分けることができる.

(b) 皮内テスト

こうして得られた 12 個の各画分をそれそれ PPD と 混和して，PPD 弱陽性者の皮内に投与才ると，Fr．3， 4, 5 は局所的に PPD 皮内反応を增强させ, 生検組織像 からはFr， 3 に最む強いDTH 反応増强作用が認めら れた.しかしこれだけでは recipientのDTHの非特 異的增强か，あるいは donor からの DTH の伝達に上 るものかは不明である。この伝達活性の有無を検索する ためには recipient が全く感作を受けていない抗原を用 いなければこの点は解明されない，そこで日本では全く 報告のない coccidioidomyosis に注目し, coccidioidin (Cocc) に対する DTH の伝達について検索した（図 2 a). すなわち, $\operatorname{Cocc}(+) \cdot \operatorname{PPD}(-)$ 米国人から Fr. 3 
-5 を作製し、これを Cocc (一) PPD ( $( \pm)$ 日本人の右 上腕皮下に投与し，左前腕で Cocc，PPD 皮内反応を行 なったＰPD 反応は增强されたが，Coceに対する皮内 反応の陽転化は認められなかった．同様の目的で SK/SD $(+) \cdot$ histoplasmin (Hist) $(+) \cdot \mathrm{PPD}(-)$ 米国人健康者

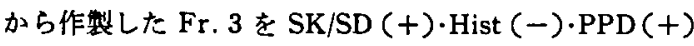
の日本人にそれぞれの抗原とともに皮内注射した（図 2 b ). Hist 皮内反応の陽転化はみられなかったが，SK/ SD.PPD 反応は明らかに增強された，以上の結果から， LD 中には donor DTH には関係なく, recipient が有 する DTH のみを非特異的に増强し, Lawrence ${ }^{1,5-6)}$ の いうTFとは明らかに異なる物質, すなわち augmentor が存在する.

(3) 免疫抑制活性

LD 中には DTH 反応の抑制因子が存在することを Kirkpatrick9)，Gottlieb ${ }^{7,10)}$ らが示唆している。著者 $ら^{8,11-12)}$ も，LDを投与した部位に近いほど DTH 反応 の增強の程度が弱い現象を認め，LD 中の DTH 反応抑 制因子の存在を報告している。また, in vitroでも Herlin ら 24)は LD 添加により, Tr 中の cAMP が增加 ナることから、サプレッサーT細胞を活性化する物質の 存在を想定している.

(4) Interferon (IFN) 誘起活性

$\mathrm{Khan}^{22)}$ らは 5 単位の LD (1 単位 $=10^{8}$ リンパ球から 作製）を健康者に投与し，血清中の IFN 活性を plaque reduction 法で検卖している．LD 投与後，6時間，24 時間ではそれぞれ，100，75 units/ml の IFN 活性が認 められ，48 時間後には消失することからウイルス疾患 における LD 治療は週 3 回投与を要すると述へている.

以上のように，LD 中には DTH の伝達・増強・抑制， IFN 誘起などの活性が認められるほか, in vitro でも

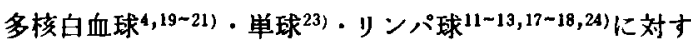
る多彩な勃果が報告されている．このうち，何れかの作 用を期待して臨床匛用しようとする場合，その生物活性 物質をできるだけ純化した形で投与する方が望ましい が，純化した活性物質を大量作製するテクニック上の問 題や，疾患によってはいくつかの活性物質の総合的効果 を必要とするという可能性もあり，今後に残された課題 であるといえる。

\section{Leukocy te dialysate (LD) の臨床応用}

ここで臨床応用に用いた LD はすへてて，大阪府赤十字 血液センターから提供を受けたもので，一般健康者白血 球から作製されたものである。したがって，日本人の平 均的な DTH を伝達するという意味合いもなくはない
がむしろ，その他の生物活性に主眼をおいた治療と言 える.ここでは治療対象を感染症およびその類縁疾患に しほり，LD の治療勃果について述べる.

\section{1) 萧瘄滕疮症}

本症は手掌・足䟽の無菌性膿疮・小水疮および紅斑を 主症状とし, 皮疹の增悪・寛解を繰り返す難治性皮痛疾 患である.ここでは，本学耳鼻咽喉科を受診した 15 名 の掌蹠腽疮症患者において行なった LD 投与の結果 ${ }^{36)} に$ ついて述へる（表 2). LD 投与前の PPD 反応は 3 名が 疑陽性，12名は陽性であったが，週 1 単位ずっの LD 投 与により全例が陽性となり, 平均 3 単位投与後に PPD 反空は最高となり，以後はしだいに減弱した．治療勃果 の判定は皮沴が消失し, 6 力月間の追跡調査でも全く再 発のみられないものを完全宽解(H)，皮疹の消失または 減少したものを効果あり(十)として表 2 に示した. 15 例中 1 例は完全寞解, 10 例に効果を認めた. 図 $3 \mathrm{a}$ は症 例 9 の LD 投与前の皮疹で LD 3 単位投与後, 明らか な皮㥄の減少を認める(図 $3 \mathrm{~b}$ ). 图 $3 \mathrm{c}$ は症例 15 の LD 投与前の手掌の皮疹で，図 $3 \mathrm{~d}$ は 2 単位の LD 投与後の 手掌で皮疹は完全に消失している。このような臨床的勃 果は平均 3 単位の $L D$ 投与後に得られ，15 例中 11 例に 臨床的改善が認められた。

本症は扁桃摘出 ${ }^{37}$ が著効を呈することから，病巣感染 の二次疾患の1つとされてきたが，その発症のメカニズ ムに関しては不明な点が多い，最近，榎本ら ${ }^{38}$ ) 扁桃陰 窝上皮上足底皮盧表皮との共通抗原性を見出し，慢性炎 症の過程で修飾された扁挑陰窝上皮抗原に対する液性ま たは細胞性免疫反応が共通抗原性のある掌蹠を target として障害性に作用する可能性を示した。この仮説のも とで推測すれば，LD の投与刘果の発現機序について， 2 つの立場から説明が可能である. 第 1 には扁桃を中心 とする病单中の病原体に対する細胞性免废の增強に上る 病巣の治瘜が考えられ，扁摘が有効なことからも説明し うる. 第2 には LD 中に存在する DTH 抑制作用によ り，自己の皮虚に対する細胞障害性リンパ球作用の抑制 という可能性もある。しかし，いずれの作用に起因する かは LDから，それぞれの活性物質が分離されなければ 解明され得ない.

\section{2) Subacute sclerosing panencephalitis} (SSPE)

現在，SSPE に対しては決定的な治療法がなく，一部 で LDに上る治療が行なわれている39,40)。その臨床的有 珈性は報告者により異なるが，SSPE 早期における LD 投与は試みるべき価值があるとされる.

大阪府赤十字血液センターの集計では 7 例の SSPE に 
表 2 掌䟷膿疮症

\begin{tabular}{cccccc}
\hline 症例 & 年龄・性 & 罹病期間 & 皮疹部位 & LD全使用量 & $\left.\begin{array}{c}\text { 臨床効果 } \\
(\text { LD使用量) }\end{array}\right)^{* *}$ \\
\hline 1 & $73 \mathrm{M}$ & $5 \mathrm{Y}$ & P. & 6 & - \\
2 & $39 \mathrm{~F}$ & $5 \mathrm{Y}$ & P.S. & 1 & - \\
3 & $49 \mathrm{~F}$ & $2 \mathrm{M}$ & P.S. & 4 & - \\
4 & $27 \mathrm{M}$ & $3 \mathrm{Y}$ & P.S. & 10 & - \\
5 & $46 \mathrm{~F}$ & $4 \mathrm{Y}$ & S. & 5 & $+(2)$ \\
6 & $40 \mathrm{~F}$ & $1 \mathrm{Y}$ & S. & 2 & $+(2)$ \\
7 & $37 \mathrm{~F}$ & $5 \mathrm{Y}$ & P.S. & 3 & $+(2)$ \\
8 & $67 \mathrm{~F}$ & $13 \mathrm{Y}$ & P.S. & 5 & $+(2)$ \\
9 & $74 \mathrm{M}$ & $4 \mathrm{M}$ & P. & 5 & $+(3)$ \\
10 & $55 \mathrm{~F}$ & $5 \mathrm{Y}$ & P.S. & 9 & $+(7)$ \\
11 & $60 \mathrm{M}$ & $3 \mathrm{Y}$ & P.S. & 8 & $+(1)$ \\
12 & $62 \mathrm{M}$ & $6 \mathrm{M}$ & P.S. & 10 & $+(4)$ \\
13 & $32 \mathrm{~F}$ & $3 \mathrm{M}$ & P.S. & 8 & $+(4)$ \\
14 & $49 \mathrm{M}$ & $1 \mathrm{M}$ & S. & 4 & $+(3)$ \\
15 & $39 \mathrm{~F}$ & $2 \mathrm{~W}$ & P. & 2 & $+12)$ \\
\hline
\end{tabular}

* P. : palm, S. : sole

** 臨床効果発現までのLD使用量

a

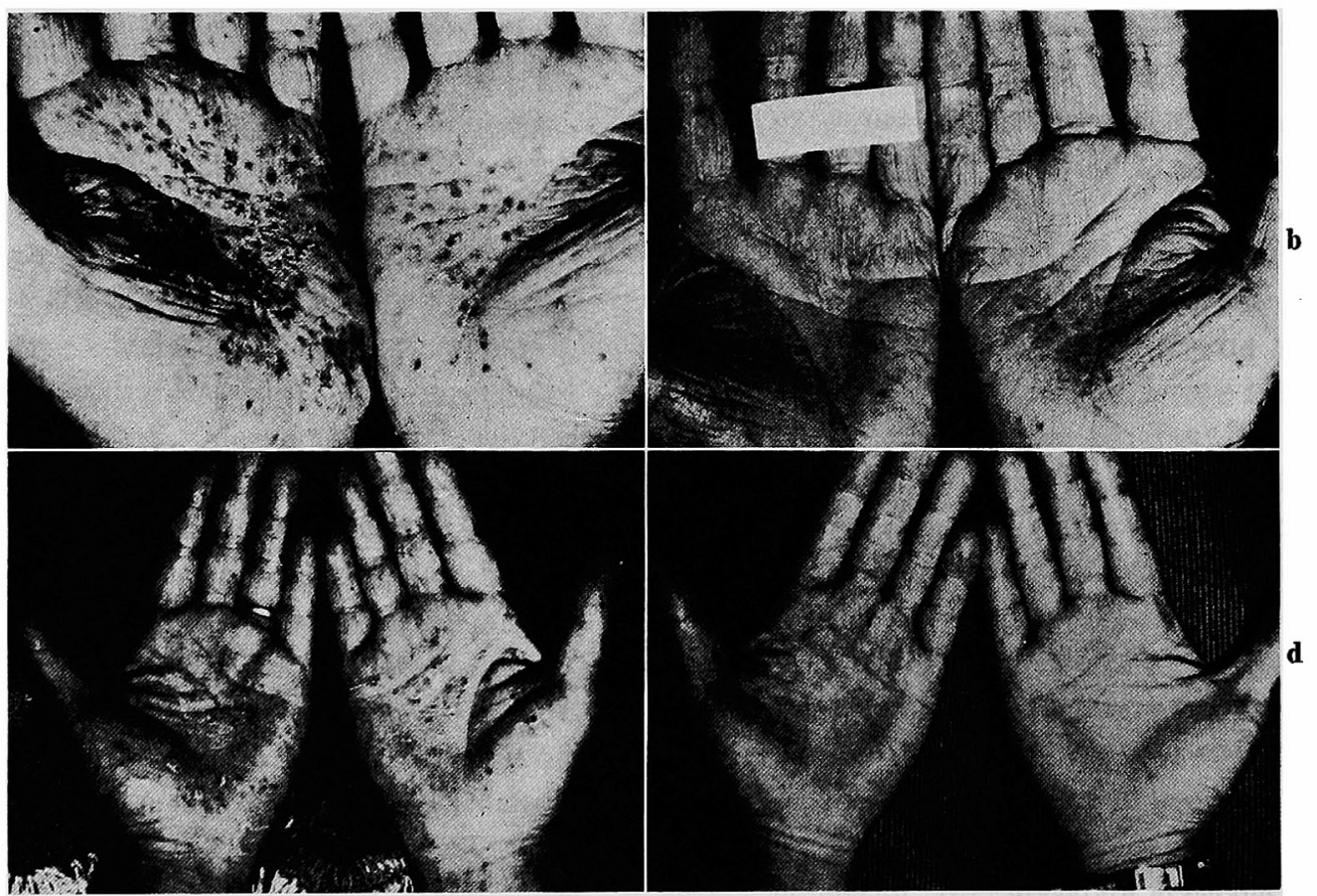

図 3 掌蹠膿疮症

LD 投与が行なわれ， 2 例に臨床的効果が認められてい

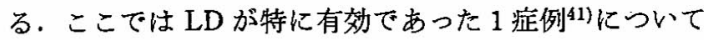
述べる(図 4).
症例は 19 歳男性. 約 1 年くら以前加ら，視力低下. 四肢脱力・間代性痙等 - ミオクローヌス発作などの神経 症状がしだいに進行し, 髄液中の蛋白・リンパ球の増加; 


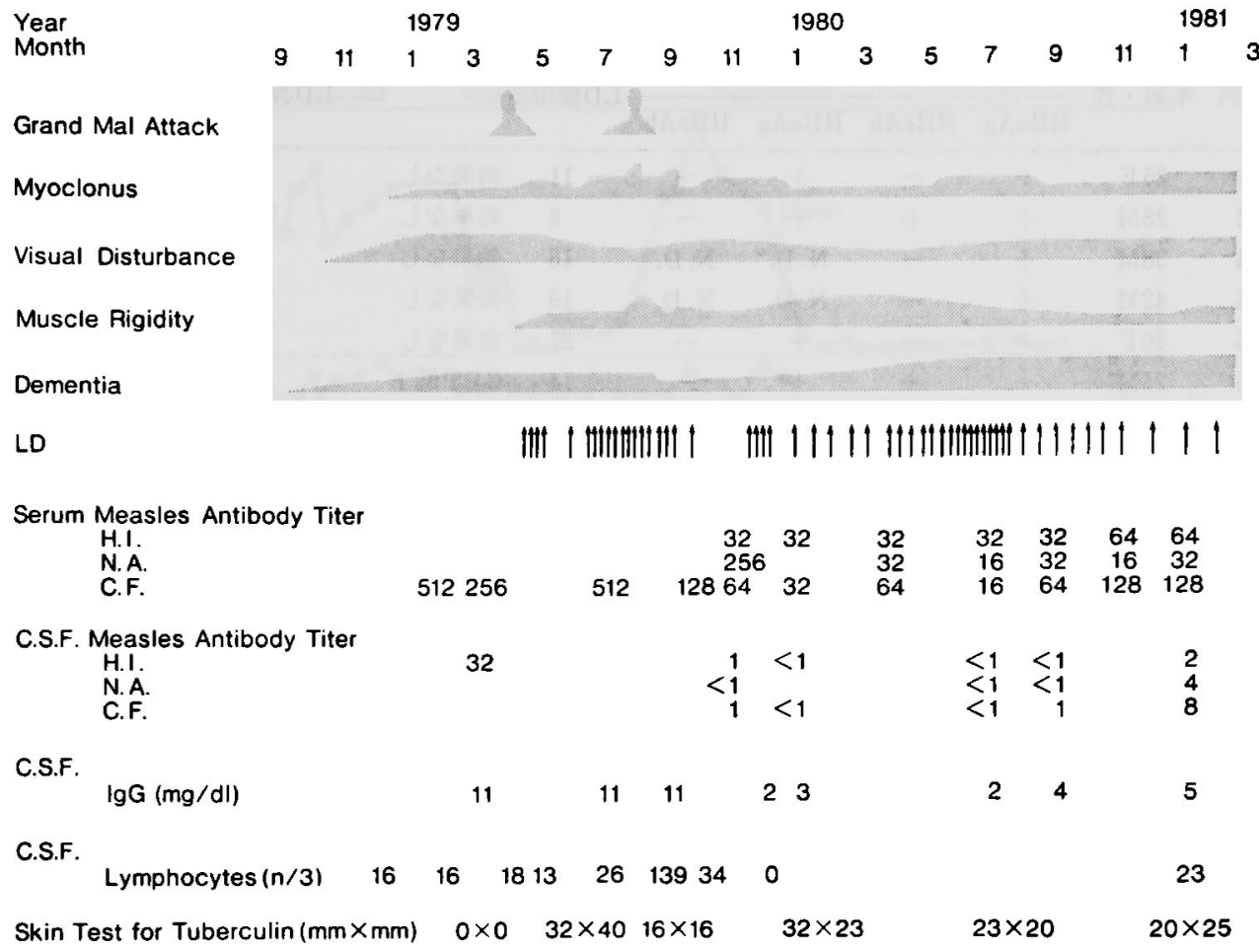

図 4 Subacute sclerosing panencephalitis

血清および髅液中の麻疹抗体洒の著增, EEGにおける periodic synchronous discharge なとから, SSPE. Jabbour ら ${ }^{42)}$ の第 2 期と診断された．入院後，神経症状 がしたいに増悪したため，週 1〜2 単位の LD 投与を開 始した，LD 投与後まもなく，PPD 反応は陽転化し，症 状增悪は停止し, 視力は軽度改善され，步行や簡単な会 話は可能となった．約 6 力月後には血清および髄液中の 麻疹抗体価は著減し, 髅液中の IgG・リンパ球も減少し たが，EEG では明らかな改善は認められなかった。本 症は自然寛解の可能性も否定はしえないが，血清および 轲液中の麻疹抗体価の低下 . PPD 陽転化などから, 症 状の增悪停止は LD 投与によるものと考えている。な お，本患者は発症後， 3 年 10 力月を経過した現在も週 1 回の LD 投与により, 症状の進展はほとんど認められ ない.

SSPE は一般に麻骖抗体価が高值にもかかわらず，治 虑に至らないことから，液性免疫の成立だけでは治療の 十分条件とはなりえない，そればかりではなく，感染細 胞膜上のウイルス抗原に麻疹抗体が結合し，免疫監視機 構からの escape 現象を起こさせたり
体が細胞性免疫機序を抑制するという報告44)もある・一 方，麻疹䍜患時には一般に細胞性免疫が低下寸ることが よく知られており，これに基うくく麻疹ウイルスの排除機 構の低下が本症の根底にあると想像される．理論的に は, 日本人の大部分が麻疹ウイルスに対し免疫能を有す ると考えられるため,これらの人からの DTH の伝達や， 患者の低下した細胞性免疫能の非特異的增強, さらには IPN 誘起活性などを期待して，本症に LD を投与する ことは理にかなっているが, 感染の場としての神経細胞 の再生がないことを考慮すると, 早期の LD 投与が望ま れる。

\section{3）慢性肝炎}

慢性肝炎, 特にB型慢性肝炎に対し, $\operatorname{HBsAg}(-)$. $\mathrm{HBsAb}(+)$ の人から LDを作製し, HBV に対する細 胞性免疫能を伝達することを主目的として, LD 投与が 行なわれている。しかし，その效果については報告者に より異なり，一致した結論は得られていないが, Shulman ${ }^{29)}$ ，高橋ら ${ }^{28)}$ はその有效性を報告している．

著者らも予備実験の域を出ないが, 18 名の $\mathrm{HBsAg}$ （十）の慢性肝炎患者に LD 投与を試みた（表 3). 投与 
表 3 B 型慢性肝炎

\begin{tabular}{|c|c|c|c|c|c|c|c|}
\hline \multirow{2}{*}{ 症例 } & \multirow{2}{*}{ 年䊩・性 } & \multicolumn{4}{|c|}{ LD使用前 } & \multirow{2}{*}{ LD使用量 } & \multirow{2}{*}{ LD投与後 } \\
\hline & & $\mathrm{HBsAg}$ & HBsAb & $\mathrm{HBeAg}$ & $\mathrm{HBeAb}$ & & \\
\hline 1 & $26 \mathrm{~F}$ & + & - & + & - & 11 & 効果なし \\
\hline 2 & $28 \mathrm{M}$ & + & + & + & - & 8 & 効果なし \\
\hline 3 & $38 \mathrm{M}$ & + & - & N. D.* & N. D. & 16 & 効果なし \\
\hline 4 & $42 \mathrm{M}$ & + & - & N. D. & N. D. & 19 & 効果なし \\
\hline 5 & $50 \mathrm{~F}$ & + & - & + & - & 21 & 効果なし \\
\hline 6 & $25 \mathrm{M}$ & + & + & + & - & 14 & GPT 低下 \\
\hline 7 & $41 \mathrm{M}$ & + & - & N. D. & N. D. & 22 & GPT低下 \\
\hline 8 & $71 \mathrm{~F}$ & + & - & N. D. & N. D. & 22 & GPT低下 \\
\hline 9 & $16 \mathrm{~F}$ & + & - & + & - & 7 & GPT 正常化 \\
\hline 10 & $30 \mathrm{M}$ & + & - & + & - & 18 & GPT 正常化 \\
\hline 11 & $38 \mathrm{~F}$ & + & - & N. D. & N. D. & 8 & GPT 正常化 \\
\hline 12 & $43 \mathrm{M}$ & + & - & - & + & 8 & GPT 正常化 \\
\hline 13 & $36 \mathrm{M}$ & + & - & - & + & 8 & GPT 正常化, HBsAg低下 \\
\hline 14 & $22 \mathrm{M}$ & + & - & N. D. & N.D. & 31 & GPT 正常化,HBsAb 陽性化 \\
\hline 15 & $43 \mathrm{~F}$ & + & - & N. D. & N. D. & 4 & GPT 正常化,HBsAb 陽性化 \\
\hline 16 & $33 \mathrm{~F}$ & + & - & + & - & 12 & GPT 低下, HBe serocon. *** \\
\hline 17 & $25 \mathrm{~F}$ & + & - & + & - & 11 & GPT正常化,HBe serocon. \\
\hline 18 & $24 \mathrm{M}$ & + & - & + & - & $4^{* *}$ & GPT正常化.HBe serocon. HBsAg 低下 \\
\hline
\end{tabular}

方法は症例によこて多少異なるが，基本的には 1 単位ず つ週 3 回投与を 2 週間行ない，以後は週 1 単位ずつの投 与を持続した。 なお，症例 1〜17 は LD 単独投与, 症例 18 は IFN- $\alpha$ と併用投与を行なった。 18 例の $\mathrm{HBsAg}$ 陽性者のうち，2 例（症例 13，18）に RPHA 法で $10^{2}$ 以上の HBsAg 価の低下が認められたが，残りの16 例 は変化なく, HBsAg の陰性化した症例はなかった。 HBsAb に関しては，LD 投与前加 $5 ， 2$ 例 (症例 2, 6) がすでに陽性であったが，HBsAb 陰性の16例中 2 例 （症例 14，15）に HBsAb の陽性化をみた。 HBeAg は 18 例中 11 例にのみ検索がなされたにすぎないが，その 11 例中 2 例（症例 12，13）は LD 投与前に $\mathrm{HBeAg}$ 加 ら $\mathrm{HBeAb}$ 一 seroconversion しており, 残りの $\mathrm{HBeAg}$ （+）の 9 例中 3 例（症例 16, 17, 18）に $\mathrm{HBeAg}$ 加 HBeAb への seroconversionが認められた. LD 投与前 の血清 GPT は 18 例の全例が上昇していたが，18 例中 4 例は明らかに低值となり，9例は完全に正常化した。 それらの症例のうちから，LD と IFN- $\alpha$ との併用によ り効果の想められた症例 18 について述へる（図 5).

症例は 24 歳の男性. 2 年前加ら肝機能異常を指摘さ れ, HBsAg, HBeAg ともに陽性で肝生検により, 慢性
活動型肝炎と骖断された。まず, 初回 320 万単位の IFN- $\alpha$ を投与し，しだいに投与量を減少させっつ，週 1 回，6 週間にわたり総計 1,040 万単位の IFN を投与 した.しかし，臨床的には全く無効であった３週間後， IFN を隔日に 8 週間にわたり, 総計 3,790 万単位を投 与したところ，DNA polymerase (DNAP) はしだいに 低下し，血清 GPT む低下傾向を示したが，投与中止と ともに DNAP は再上㫒した. さらに 3 週間後, LD と IFN- $\alpha$ との併用を試みた. LD は週 1 回投与を 4 週間, 計 4 単位を投与し，IFNは隔日に 180 万単位を 20 日間， 総計 1,800 万単位を投与した。 DNAP は低下し，投与 終了直後には $\mathrm{HBeAg}$ から $\mathrm{HBeAb}$ 一の seroconversion が認められ，HBsAg \& RPHA 法で $2^{10}$ から $2^{4}$ まで低 下したが，4 カ月間の観察期間中に $2^{7} \sim 2^{8}$ 一と増加傾向 を示すものの, HBeAg は陰性で血清 GPT む正常の状 態が持続している.なお，HBsAb は全経過を通して陰 性であった。

B 型慢性肝炎における治潦効果の判定は個々の症例に おいては自然経過との区別がきわめて困難で今後症例を 增やして検索すべき問題であるが，(1) IFN との併用例 をも含めて，検索した $\mathrm{HBeAg}$ 陽性例の 9 例中 3 例に 


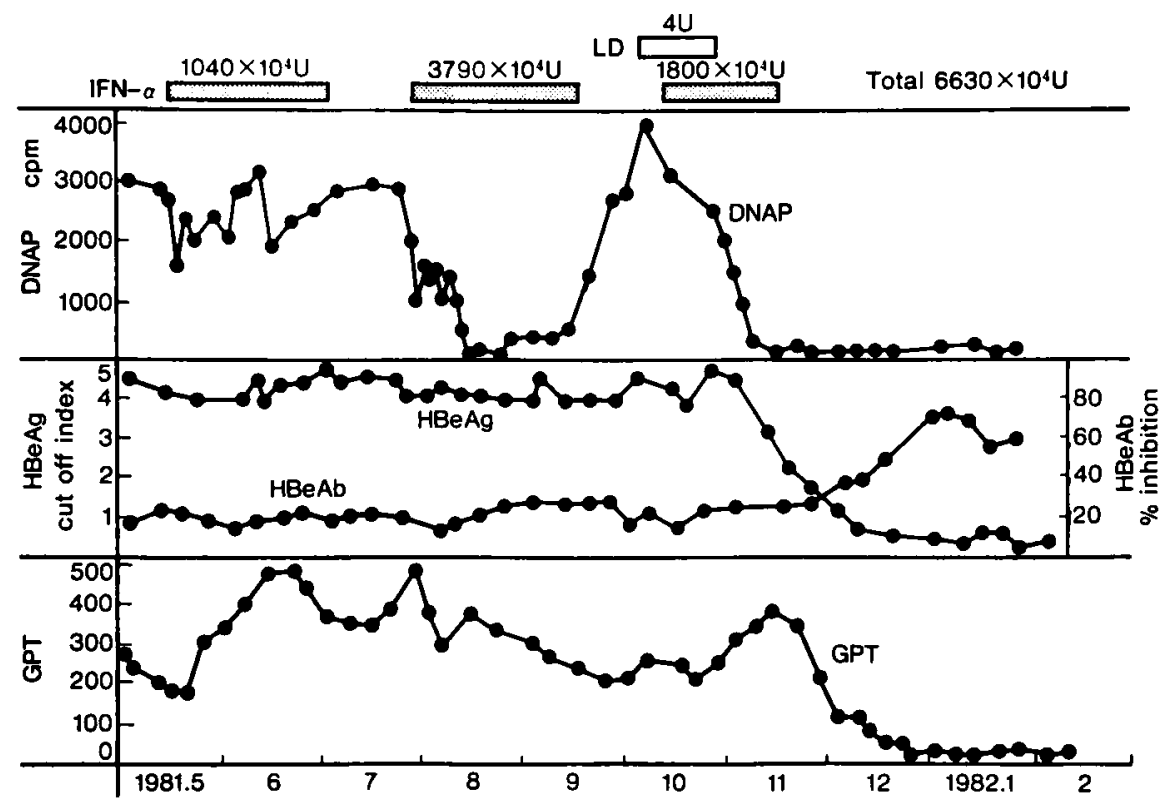

图 5 B型慢性胿炎 - LD と IFN の併用

HBeAg から HBeAb への seroconversion を認めたこ と，(2) 18 例中 4 例に血清 GPT の低下，9例に正常化 が得られたこと，(3) LD 投与は注射時の軽い疼痛以外 の副作用を認め才゙，外来投与が可能であったこと，(4) LD 投与により増覀した症例のなかったこと，などを考 慮すると，LD 投与は本症に対し，試みるべき治療法の 1つと考えられる.

B型倡性肝炎の発症機序としては, 無症候性 HBV キ ヤリヤーの存在することから，HBV の侵襲だけでは肝 炎は発症せず, HBV の感染に宿主の免疫反応が加わっ て，はじめて発症すると考えられる：さらに，慢性化の 要因としては HBV 排除機構の低下が重要視されてい る45).こうした観点から LD 治療効果を考察すると，ま ホ， 日本人の平均的な HBVに対する細胞性免疫能を患 者に伀達するか，あるいは患者の HBV に対する細胞性 免疫能を非特異的に增強し，HBV を排除するための免 度機棈を賦活させるとともに IFN 誘起活性によっても， 抗ウイルス効果を発現したと思われる．さらに，LD 投 与により，18 例中 13 例に血清 GPT の低下あるいは正 常化が認められたことから， HBV 感染肝細胞に対する 宿主の免疫反応が LD 中の抑制活性により抑制され，慢

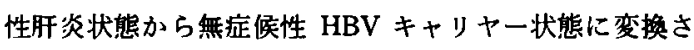
れたという可能性もある。いずれにしても，LD 単独投 与では慢性肝炎から HBV を完全に排除するほどの効力 はなかったが，今後 IFN などの併用療法を含め，確か な手ごたえを感じる。

\section{おわりに}

従来から，LDによる臨床応用はTF 作用に主眼がお かれてきた，しかし，ここでは LD 中に存在する多くの 生物学的活性について述へ, immunoregulator として の立場から，LDの治療勃果とその発現機序を考察した。

\section{謝 辞}

稿を終えるにあたり，LD を提供していただいた大阪 府赤十字血液センター 山口英夫先生, 赤司克彦先生, 田中成害先生に深く感賭いたします。 また，本研究の臨 床面において御協力いただいた和歌山県立医科大学耳鼻 咽喉科 田端敏秀教授, 坦内 弘先生, 精神神経科菊 岡牧子先生, 小览科 小池通夫助教授, 内分泌内科 南 条輝志男先生, 大阪府赤十字病院内科 清水達夫先生, 奈良県立病院内科松森 武先生に媣的いたします。 
1) Lawrence, H.S. : The transfer factor in humans of delayed skin sensitivity to streptococcal $M$ substance and to tuberculin with disrupted leucocytes. J. Clin. Invest., 34 : $219,1955$.

2）斎藤晃治, 大野友坜, 中㟄宽和, ほか：トランス ファーファタター, 治療学, $18: 76,1982$.

3）玉置信应，乾治郎，大野友彦，ほか：白血球抽 出物の adjuvant 物質一Transfer factor の特異 性之の関連. 臨床免疫, $12: 375,1980$.

4) 斎藤晃治, 玉固信彦, 西原 亨, ほか: Transfer factor 生物化学的性澌.アレルギー, $28: 430$, 1979.

5) Lawrence, H.S. : Transfer factor. Adv. Immunol., II : 195, 1969.

6) Lawrence, H.S. : Transfer factor in cellular immunity. In "The Harvey Lectures. Series 68 ', Academic Press Inc., New York, 1974, p. 239 .

7) Gottlieb, A.A., Sutcliffe, S., Saito, K., et al. : Modification of intradermal delayed hypersensitivity by components of leukocyte dialysates. In "Immune regulators in transfer factor" (edited by Khan, A., Kirkpatrick, C.H. \& Hill, N.O.), Academic Press Inc., New York, 1979, p. 339.

8）中笔寛和，斎藤晃治：Leukocyte dialysatesTransfer factor $の$ 問題点につけて. 感染.炎症 - 免疫, $12: 91,1982$.

9) Kirkpatrick, C.H. and Gallin, J.I. : Suppression of cellular immune responses following trans. fer factor: report of a case. Cell. Immunol., $15: 470,1975$.

10) Gottlieb, A.A., Foster, L.G. and Waldman, S.R., et al. : What is transfer factor? Lancet, II : 822, 1973.

11）彩藤晃治, 松森 武, 乾 治郎, ほか：Transfer factor の生物化学的性罂一Transfer factor 活性 とその抑制因子. 臨休货疫, $9: 725,1977$.

12）斎藤晃治：トランスファー・ファクタ一. Mook Mediscience No. 1. 免疫 (小林 登編), メディ サイエンス社. 1981, p. 95.
13) Cohen, L., Holzman, R.S., Valentine, F.T., et al. : Requirement of precommitted cells as targets for the augmentation of lymphocyte proliferation by leukocyte dialysates. J. Exp. Med., $143: 791,1976$.

14) Gottlieb, A.A., Foster, L.G., Saito, K., et al. : Use of fluorescamine to identify a nonspecific component of human "transfer factor". In “Transfer factor. Basic properties and clinical applications " (edited by Ascher, M.S., Got. tlieb, A.A. and Kirkpatrick, C.H.), Academic Press, New York, 1976, p. 263.

15) Gottlieb, A.A., Maziarz, G.A. and Tamaki, N., et al. : The effect of dialyzable products from human leukocyte extracts on cutaneous delayed-hypersensitivity response. J. Immunol., $124: 885,1980$.

16) Gottlieb, A.A., Saito, K., Sutcliffe, S., et al. : Biochemical analysis of dialyzable leukocyte extracts. J. Reticuloendothel. Soc., .21:403, 1977.

17) Valdimarsson, H. and McGuire, R.L. : Crude transfer factor preparations stimulate trypsinized human lymphocytes to form rosettes with sheep red cells. Clin. Exp. Immunol., 29 : 261, 1977.

18) Saito, K., Tamaki, N., Foster, L.A., et al. : Inhibition of DNA synthesis in lymphocytes by dialyzable components of human leukocyte extracts. Cell. Immunol., $31: 311,1977$.

19) Gallin, J.I. and Kirkpatrick, C.H. : Chemotactic activity in dialyzable transfer facter. Proc. Natl. Acad. Sci., 71: 498, 1974.

20）大野友彦，川端良樹，玉置信彦，ほ加：白血球抽 出物中に杮れた leukocy te random locomotion inhibition activity - Transfer factor との関連性 について.アレルギー, $28: 723,1979$.

21) Wilson, G.B. and Fudenberg, H.H. : Effects of dialyzable leukocyte extracts with transfer fac. tor activity on leukocyte migration in vitro. II . Separation and partial characterization of the components in DLE producing antigen-depen. 
dent and antigen-independent effects. J. Lab. Clin. Med., 93 : 819, 1979.

22) Khan, A. : Transfer factor in viral diseases. The Lancet, II : 328, 1978.

23) Sandler, J.A., Smith, T.K., Manganiello, V.C., et al. : Stimulation of monocyte cGMP by leukocyte dialysates. An antigen-independent property of dialyzable transfer factor. J. Clin. Invest., $56: 1271,1975$.

24) Herlin, T., Jensen, J.R., Thestrup-Pedersen, K., et al. : Dialyzable leukocyte extract stimulates cAMP in $\mathrm{Tr}$ lymphocytes. Allergy, $36: 337,1981$.

25) Kirkpatrick, C.H. and Smith, T.K. : Chronic mucocutaneous candidiasis: Immunologic and antibiotic therapy. Ann. Intern. Med., 80 : 310, 1974.

26) Lawton, J.W.M., Costello, C., Barclay, G.R., et al. : The effect of transfer factor on neu. trophil function in chronic mucocutaneous candidiasis. Brit. J. Haemat., 33 : 137, 1976.

27) Catanzaro, A. and Spitler, L.E. : Clinical and immunologic results of transfer therapy in coccidioidomycosis. In "Transfer factor. Basic properties and clinical applications" (edited by Ascher, M.S., Gottlieb, A.A. and Kirkpatrick, C.H.), Academic Press, New York, 1976, p. 263.

28）高橋豊, 常田ひろみ, 岡田昌楌,ほか：Transfer factor による小児B型慢性肝炎治療の試み. 日本 小児科学会雑誌, $85: 956,1981$.

29) Shulman, S.T., Hutto, J.H., Ayoub, E.M., et al. : A double-blind evaluation of transfer factor therapy of HBsAg-positive chronic aggressive hepatitis: Preliminary report of efficacy. Cell. Immunol., $43: 352,1979$.

30) Moulias, R., Lesourd, B., Marescot, M., et al. : Transfer factor therapy in viral diseases: Results, adverse effects, indications. In "Immune regulators in transfer factor" (edited by Khan, A., Kirkpatrick, C.H. and Hill, N.O.), Academic Press Inc., New York, 1979 , p. 521.

31) Whitcomb, M.E. and Rocklin, R.E. : Transfer factor therapy in a patient with progressive primary tuberculosis. Ann. Intern. Med., 79 : $161,1973$.

32）崳山幸雄, 上原秀樹, 富㮹武弘, ほか2: Transfer factor の試用経験. 臨床免疫, 8:407, 1976.

33) Neihart, J.A., Christakis, N., Metz, E.N., et al. : Skin test conversion following transfer factor. A double-blinded study of normal individuals. J. Allergy Clin. Immunol., 61 : $115,1978$.

34) Spitler, L.E. : Transfer factor: failure to transfer reactity in normal human subjects. Clin. Exp. Immunol., $39: 708,1980$.

35) Ascher, M.S. and Andron, L.A.: Transfer factor in vitro: nonspecificity of component that enhance lymphocyte proliferation to antigen. Clin. Immunol. Immunopathol., 12 : $72,1979$.

36) 垣内弘, 榎本雅夫, 田端敏秀, ほ加: 掌踫朖疮症 と transfer factor (第二報). 日本扁桃研究会会 誌, $20: 19,1981$.

37) Andrews, G.C. and Machacek, G.F. : Pustular bacterids of the hand and feet. Arch. Dermatol. Syph., $32: 837,1935$.

38）榎本雅夫, 垣内 弘, 林 泰弘: 掌跐膿抱症と病

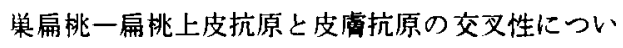
て. 日本扁挑研究会会誌, $21: 211 ， 1982$.

39) Blease, R.M., Hofstrand, H., Krebs, H., et al. : Evaluation of transfer factor in the therapy of SSPE. Arch. Neurol., $32: 503,1975$.

40）松本脩三：トランスファー・ファクター。新小児 矤学大系, $19 \mathrm{~A}$ (小林 登, 多田綮也, 藪内百治 編), 中山書洁, 東京, 1979, p. 403.

41）大野友彦, 乾 治郎. 坂辻喜久一, 注加: Transfer factor 投与後, 症状増悪の停止と麻诊抗体価の著 減をきたしたSSPEの 1 例. 臨床免疫, $14: 159$, 1982.

42) Jabbour, J.T., Garcia, J.H., Lemmi, H., et al. : Subacute sclerosing panencephalitis; A multidisciplinary study of eight cases. J.A.M.A., $207: 2248,1969$.

43) Joseph, B.S., Lampert, P.W. and Oldstone, M.B.A. : Antibody-induced stripping of surface measles antigens. An alternative mechanism for immunocytolytic blockade in SSPE. Arch. Neurol., $32: 500,1975$. 
44) Steel, R.W., Fuccillo, D.A., Hensen, S.A., et al. : Specific inhibitory factors of cellular immunity in children with subacute sclerosing panencephalitis. J. Pediatr., $88: 56,1976$.
45) Dudley, F.J., Fox, R.A. and Sherlock, S. : Cellular immunity and hepatitis-associated Australia antigen liver disease. Lancet, I : 723, 1972. 